\title{
URGENSI FILSAFAT DALAM KEHIDUPAN MASYARAKAT KONTEMPORER: Tinjauan Filsafat Islam terhadap Fungsi Moral dan Agama
}

\author{
Himyari Yusuf \\ Institut Agama Islam Negeri (IAIN) Raden Intan Lampung \\ e-mail: syaifulloh_ngukup.@yahoo.com
}

\begin{abstract}
This study reveals the function of morality and religion, especially for today's contemporary society. In fact, moral and religious issues are intimately related to human life in today's global era which has experiences a change or shift of meaning and function. Truthfully, the function of morality and religion in contemporary society barely possesses any value. Morality is noticeably a classic problem that hinders the freedom of human life, as well as religion is considerably an individual issue and another world issue (hereafter). Therefore, the focus of this study is the nature and function of morality and religion for the contemporary society, and the relationship of man, morality, and religion (Islam). Through answering the various issues above, this study uses a philosophical approach (philosophy as a method). The use aims to wholly, radically, and rationally understand what the nature and function of morality and religion for human life or for the contemporary society to the point that the understanding reaches its essential and fundamental meaning. Those issues are principally related to human and humanity. The moral and religious dimensions have been fused with the existence and essence of human life. Religion (Islam) is in accordance with the nature of humanity, and it contains the values of morality. Thus, philosophically, it implies that man, morality, and religion (Islam) is one species, and they cannot be separated. Consequently, morality and religion (Islam) should be implemented in a whole series of human life in the contemporary and global age like nowadays.
\end{abstract}

\begin{abstract}
Abstrak: Pengkajian ini menampilkan persoalan fungsi moralitas dan agama, khususnya bagi masyarakat kontemporer dewasa ini. Secara faktual persoalan moral dan agama adalah persoalan yang terkait dengan kehidupan manusia yang pada era global sekarang ini telah mengalami perubahan atau pergeseran pemaknaan dan fungsi. Secara faktual fungsi moralitas dan agama pada masyarakat kontemporer nyaris tidak memiliki nilai apa-apa. Moralitas dianggap persoalan klasik yang menghambat kebebasan hidup manusia, demikian pula agama hanya dianggap sebagai persoalan individu dan persoalan dunia lain (akhirat). Oleh karena itu yang menjadi pokok kajian dalam tulisan ini adalah apa hakikat dan fungsi moralitas dan agama bagi kehidupan masyarakat kontemporer, dan bagaimana korelasi manusia, moralitas, dan agama (Islam). Menjawab berbagai pokok persoalan di atas, dalam kajian ini akan menggunakan pendekatan filsafat (filsafat sebagai metode). Penggunakan pendekatan filsafat, dimaksudkan agar apa yang menjadi hakikat dan fungsi moralitas dan agama bagi kehidupan manusia atau bagi masyarakat kontemporer dapat pahami
\end{abstract}


secara menyeluruh, mendasar (radikal), dan rasional, sehingga sampai pada hakikatnya yang paling hakiki dan mendasar. Persoalan hakikat dan fungsi moralitas dan agama, sesungguhnya merupakan persoalan yang terkait dengan manusia dan kemanusiaan. Dimensi moralitas dan agama sejatinya telah menyatu dengan eksistensi dan esensi manusia sendiri. Agama (Islam) sesuai dengan fitrah kemanusiaan, dan di dalamnya terkandung nilai-nilai moralitas. Dengan demikian secara filosofis dapat dikatakan bahwa manusia, moralitas, dan agama (Islam) merupakan satu spesies, yang satu dengan lainnya tidak dapat dipisahkan. Oleh karena itu moralitas dan agama (Islam) harus diimplentasikan dalam seluruh rangkaian kehidupan umat manusia pada era kontemporer dan globalisasi dewasa ini.

Keywords: morality; religion; society; contemporary era

\section{A. Pendahuluan}

Filsafat sering sekali dipandang sebagai pemikiran yang membingungkan bahkan menyesatkan umat manusia. Pandangan semacam ini tentunya sangat disayangkan, karena filsafat secara esensial justru sangat penting artinya bagi kehidupan manusia, khususnya dalam menyelesaikan berbagai persoalan kemanusiaan. Filsafat secara umum adalah berpikir secara menyeluruh, mendalam, radikal dan rasional, tentang sesuatu. Menurut Syamsuddin Arif dan Dinar Dewi Kania dalam Adian Husaini, filsafat itu mencari kebenaran. Dengan bertanya secara terus menerus tentang segala hal, dari persoalan gajah sampai persoalan semut, dari soal hukum, dan politik hingga soal moral dan metafisika dan sebagainya. ${ }^{1}$ Rizal dan Misnal yang dikutip Himyari Yusuf juga mengemukakan bahwa filsafat merupakan sebuah disiplin ilmu yang terkait dengan perihal kebijaksanaan. Sedangkan kebijaksanaan merupakan titik ideal dalam kehidupan manusia, karena ia dapat menjadikan manusia untuk bersikap dan bertindak atas dasar pertimbangan kemanusiaan yang tinggi. ${ }^{2}$ Dengan demikian dapat dikatakan bahwa filsafat adalah berpikir secara menyeluruh, radikal dan rasional sebagai proses yang tanpa henti untuk mencari kebenaran secara terus menerus dan pada akhirnya dapat memahami makna segala sesuatu termasuk makna kehidupan manusia.

Berdasarkan pengertian Filsafat di atas, dapat dipahami bahwa jika istilah filsafat dilekatkan dengan Islam atau yang disebut filsafat Islam, maka filsafat Islam adalah berpikir secara menyeluruh, radikal dan rasional sebagai proses

${ }^{1}$ Adian Husaini (ed.), Filsafat Ilmu Perspektif Barat dan Islam (Jakarta: Gema Insani, 2013) , h. 13.

${ }^{2}$ Himyari Yusuf, Filsafat Ilmu (Bandar Lampung: Pusikamla, 2009), h. 3. 
yang tanpa henti untuk mencari kebenaran secara terus menerus dan pada akhirnya dipahami makna segala sesuatu termasuk makna kehidupan manusia dan seluruh rangkaian yang terkait dengannya. Tegasnya dapat dikatakan, filsafat Islam pada tataran ontologis adalah hakikat manusia dan kemanusian, dan pada tataran epistemologis bersumber pada al-Qur'an dan Sunnah NabiNya, selain potensialitas indera, akal, hati (intuisi), dan pada tataran aksilogis adalah bernilai guna bagi kesejahteraan hidup manusia lahir dan batin (jasadiah dan ruhaniah).

Syamsuddin Arif dan Dinar Dewi Kania, menegaskan bahwa dalam tradisi intelektual Islam, ditemukan beberapa istilah yang umum untuk filsafat. Antara lain, istilah hikmah, yang tampaknya dipakai untuk menimbulkan kesan bahwa filsafat bukanlah barang asing, akan tetapi berasal dan bermuara pada alQur'an. ${ }^{3}$ Kendati filsafat merupakan tradisi intelektual Islam, namun tidak sedikit yang berpandangan antipati dengan filsafat. Pandangan ini melihat filsafat sebagai barang import yang mengandung unsur-unsur ateisme, sekularisme, relativisme, pluralisme, dan liberalism. Paham-paham inilah sesungguhnya yang ditolak oleh para ulama Islam, yaitu filsafat yang menggiring pelakunya kepada sikap anti Tuhan, dan anti agama, mendewakan akal, melecehkan Nabi dan sebagainya. ${ }^{4}$

Uraian mengenai filsafat Islam di atas, dapat diinterpretasikan bahwa filsafat Islam itu erat kaitannya dengan pencarian kebenaran kemanusiaan yang bersumber pada al-Qur'an dan Sunnah, yang tidak meninggalkan indera, akal dan intuisi. Dalam Islam manusia berkedudukan sebagai khalifah Tuhan di bumi, oleh karena itu harus mamahami siapa dirinya, berada di mana, dan untuk apa dia ada. Memahami diri sebagai khalifah berarti ada keharusan untuk ikut dalam peroses pengawalan alam, dan menyadari sepenuhnya bahwa manusia berada di tengah-tengah makhluk kesemestaan lainnya (manusia sebagai sentral makhluk bumi). Kemudian karena manusia merupakan sentral makhluk kesemestaan, maka keberadaannya harus memberikan manfaat yang sebesarbesarnya bagi sesama manusia dan alam lingkungan lainnya. Dengan demikian dapat dikatakan bahwa filsafat dalam konteks kajian ini adalah sebagai pendekatan untuk menggali fungsi moral dan agama bagi kehidupan masyarakat, baik teoretis maupun praktis.

${ }^{3}$ Ibid., h. 13-14.

${ }^{4}$ Ibidh. 18. 
Penggunaan pendekatan kefilsafatan sebagaimana dimaksud di atas, agar nilai-nilai moral dan agama dapat dipahami sampai pada hakikatnya yang paling hakiki atau mendasar. Karena secara filsafati hanya pendekatan semacam itulah yang memungkinkan hakikat, fungsi moral dan agama dapat diketahui dan dipahami sebagaimana mestinya. Walaupun seperti telah disinggung sebelumnya bahwa masih banyak intelektual Muslim yang belum memahami apa, bagaimana dan untuk apa filsafat itu sesungguhnya. Bahkan masih ada intelektual Muslim yang berpandangan bahwa filsafat itu merupakan momok yang memusingkan, makhluk yang membosankan, terlalu teoretis, mengawangawang, dan bahkan mengkufurkan manusia (pandangan anti filsafat). Dalam rangka meluruskan pandangan yang miring terhadap filsafat semacam itu menurut Fazlur Rahman yang dikutip oleh Muhammad Muslih, bahwa filsafat itu sangat diperlukan untuk menerobos kemacetan dan jalan buntu yang dihadapi ilmu, baik keilmuan alam, sosial maupun humanitis, termasuk masalah-masalah keagamaan. ${ }^{5}$ Oleh karena itu Muhammad Muslih menekankan bahwa filsafat bagaimanapun adalah alat intelektual yang terus menerus diperlukan (filsafat sebagai pendekatan). Dikatakan demikian karena filsafat membiasakan akal pikiran untuk bersikap kritis-analitis dan mampu melahirkan ide-ide segar yang dibutuhkan dalam hidup manusia, maka filsafat menjadi alat yang sangat penting bagi intelektual dalam mengembangkan berbagai ilmu pengetahuan termasuk dalam agama dan teologi. ${ }^{6}$

Relevan dengan penjelasan di atas Zubaidi Mastal mengemukakan, berbagai problematika yang muncul kepermukaan, apabila tidak dipolakan dan ditampilkan dari pengkajian secara menyeluruh dan mendasar (filsafat), maka tetap akan memberikan atau menimbulkan citraan yang negatif, baik terhadap nilai-nilai moral dan agama, maupun terhadap fungsi dan tujuannya ${ }^{7}$. Demikian urgensinya filsafat menurut para pakar tersebut, yang sejatinya adalah untuk kepetingan kehidupan manusia, yaitu filsafat sebagai alat (pendekatan) dalam mengkaji dan menyelesaikan berbagai problem yang muncul dalam kehidupan manusia, khususnya bagi masyarakat kontemporer dewasa ini.

\footnotetext{
${ }^{5}$ Mohammad Muslih, Filsafat Ilmu, Kajian Atas Asumsi Dasar, Paradigma dan Kerangka Teori Ilmu Pengetahuan (Yogyakarta, Belukar, 2004), h. 29.

6 Ibid., h. 30.

7Zubaidi Mastal, IAIN dalam Kritik dan Perspektif Pembangunan (Bandar Lampung, Gunung Pesagi, 1994), h. 17-18.
} 
Lebih rinci The Liang Gie mengemukakan bahwa berbagai konsepsi dan pengertian filsafat yang berlainan, sesungguhnya dapat diikhtisarkan pada beberapa konsepsi, yang di antaranya adalah filsafat sebagai ilmu, filsafat sebagai kritik pngetahuan(pendekatan), dan filsafat sebagai pandangan hidup. ${ }^{8}$ Wibisono yang dikutip oleh Muslih mengemukakan, untuk menghindari kesimpang siuran dalam pemahaman apa itu filsafat, maka perlu dibedakan antara filsafat dengan ilmu filsafat. Pengertian filsafat yang digunakan seharihari cenderung merupakan asas atau pendirian yang kebenarannya telah diterima dan diyakini serta digunakan sebagai dasar dalam menjawab masalahmasalah fundamental yang dihadapi dalam kehidupan manusia dan filsafat yang ini diberi konotasi filsafat sebagai pandangan hidup. ${ }^{9}$ Wibisono menambahkan bahwa filsafat sebagai ilmu tidak berbeda dengan cabang-cabang ilmu lainnya. Namun llmu filsafat mempunyai perbedaan pada objek formalnya. Ilmu filsafat mempertanyakan hakikat (substansi) atau apanya objek sasaran yang diteliti dan objek itu dipahami dari keutuhan atau totalitasnya. ${ }^{10}$

Berdasarkan berbagai pandangan di atas, secara empirik menunjukkan bahwa filsafat sangat urgen bagi kehidupan manusia. Urgensi filsafat tidak hanya pada bidang ilmu pengetahuan, tetapi meliputi seluruh aspek kehidupan manusia, termasuk permasalahan moral dan agama. Terlebih bagi masyarakat kontemporer yang tengah menghadapi permasalahan sangat kompleks, atau hampir pada setiap aspek kehidupan menghadapi problem yang harus diselesaikan.

Secara faktual kehidupan masyarakat kontemporer sudah banyak mengalami berbagai kemajuan, dan kemajuan tersebut secara kausalitas seiring dengan perkembangan ilmu pengetahuan yang sangat pesat dan spektakuler. Fakta menunjukkan bahwa perkembangan ilmu pengetahuan telah melahirkan berbagai teknologi canggih, terutama teknologi dalam bidang komunikasi dan transformasi. Kedua bidang teknologi telah mampu mengubah peradaban manusia yang luar biasa. Dunia seakan tanpa batas, semua menjadi mengglobal dan terasa tanpa sekat atau demarkasi pembatas yang memisahkan negara yang

${ }^{8}$ The Liang Gie, Suatu Konsepsi Kearah Penertiban Bidang Filsafat (Yogyakarta, Karya Kencana, 1987), h. 1-2.

${ }^{9}$ Mohammad Muslih, Filsafat Ilmu ..., h. 27.

10Ibid., h. 28. 
satu dengan lainnya, komunitas yang satu dengan lainnya, bahkan antara individu dengan individu lainnya. Namun disisi lain kemajuan tersebut di atas juga harus diakui telah menimbulkan berbagai kegamangan sikap hidup dan kegersangan jiwa. Kegamangan sikap hidup dan kegersangan jiwa yang dialami masyarakat pada era belakangan dapat dikatakan sebagai akibat dari menipisnya nilai-nilai moral dan agama. Moral dan agama cenderung ditempatkan pada lahan yang tidak bertuan, dalam arti seakan tidak ada manfaat dan tidak ada kaitannya dengan kehidupan praktis manusia. Fakta menunjukkan bahwa masyarakat kontemporer secara esensial telah ber-Tuhan kepada kebebasan (libralisme), dan kebendaan yang sesuai dengan keinginan dan kepuasan nafsu keserakahan, sehingga kebenaran yang menjadi ukuran adalah yang sesuai benda dan dengan nafsu. ${ }^{11}$ Oleh karena itu penulis menganggap hal tersebut menjadi sangat penting untuk dikaji secara menyeluruh, mendasar, bagaimana fungsi moral dan agama bagi kehidupan masyarakat kontemporer menurut kajian filsafat.

Kajian tentang urgensi filsafat dalam kehidupan masyarakat kontemporer spesifik mengenai fungsi moral dan agama dalam kajian ini tentunya menggunakan pendekatan kefilsafatan seperti telah disebutkan sebelumnya. Penggunaan pendekatan filsafat tersebut bertujuan untuk memahami hakikat moral dan agama dan sekaigus nilai-nilainya dapat difungsikan secara totalitas, dan komprehensif, sehingga nilai-nilai moral dan agama dapat dikonkretisasikan dalam berbagai tatanan kehidupan praktis manusia khususnya pada masyarakat yang sedang mengglobal dewasa ini. Dengan demikian apa yang menjadi kegamangan perilaku dan kegersangan hidup manusia akibat keringnya nilai-nilai moral dan agama, dapat diminimalisir, dan akhirnya nilainilai tersebut dapat diterapkan sesuai hakikat, fungsi dan tujuan yang seharusnya. Artinya tidak perlu ada lagi yang menyangkal akan pentingnya nilai-nilai moral dan agama bagi kehidupan manusia.

Kehidupan masyarakat pada era kontemporer atau yang juga disebut postmodern dewasa ini, yang paling faktual adalah ditandai oleh mengglobalnya peradaban. Paradigma kehidupan semacam itu secara umum dipacu oleh

\footnotetext{
1999). h. 85.

${ }^{11}$ Himyari Yusuf, Filsafat dalam Berbagai Problematika Kehidupan (Bandar Lampung: Pusikamla,
} 
berbagai kecanggihan berpikir dan pesatnya perkembangan ilmu pengetahuan yang disertai dengan berbagai teknologi yang spektakuler sebagaimana telah disinggung di atas. Penting untuk dipertegas kembali bahwa sebagai implikasi dari perkembangan ilmu pengetahuan dan teknologi telah berhasil menghantarkan kehidupan manusia sampai ketatanan yang sangat mengagumkan dan bahkan membahagiakan secara fisik. ${ }^{12}$ Misalnya seseorang ingin berkomunikasi dengan orang lain yang berada ditempat yang jauh, baik itu untuk urusan bisnis, maupun urusan politik dan lain sebagainya, tidak perlu lagi bersusah payah, cukup dengan menggunakan teknologi komunikasi, dan dalam hitungan detik saja sudah bisa dilakukan dan diselesaikan. Selain itu masyarakat yang sebelumnya masih bersifat agraris telah berubah dan berkembang menjadi masyarakat industrialis. Fakta semacam ini dapat dilihat di daerah-daerah seluruh pelosok tanah air. Seperti disinyalir oleh Quraish Shihab, bahwa tidak sedikit orang yang menuntut perubahan di segala hal, termasuk nilai-nilai dasar agama. Agama Islam menurut kelompok tertentu harus juga menyesuaikan diri dengan perubahan itu..$^{13}$ Namun perlu dipertegas kembali bahwa pada sisi yang lain perubahan itu telah banyak pula menimbulkan krisis atau kemiskinan yang sangat mendasar. Misalnya telah terjadi kekeringan nilai-nilai moral dan spiritual (miskin spiritualitas), bahkan pada tatanan yang lebih esensial paradigma kehidupan global dan teknologi canggih dewasa ini telah melahirkan keterpurukan nilai-nilai kemanusiaan yang sudah sampai pada tingkat yang sangat memprihatinkan.

Kehidupan masyarakat kontemporer yang mengetepikan nilai-nilai moral dan agama, bahkan menganggapnya nilai-nilai tersebut sebagai realitas yang kosong tanpa makna, agama hanya dianggap sebagai persoalan pribadi dan masalah alam lain (akherat), sehingga ranah nilai-nilai agama yang dilandasi oleh keyakinan kepada Tuhan sebagai simpul dari keimanan dianggap tidak lebih tinggi dari nilai-nilai kemewahan fisik material semata. Semua yang bersifat fisik-material merupakan tolok ukur segala sesuatu, yang pantang diragukan akan kebenarannya. ${ }^{14}$ Karakteristik kehidupan seperti itulah yang dikemukakan oleh Zubaidi Mastal, bahwa kehidupan manusia di era posmodern

12Ibid., h. 86.

${ }^{13}$ M. Quraish Shihab, Wawasan al-Qur'an (Bandung: Mizan, 2007), h. 12.

${ }^{14}$ Himyari Yusuf, Filsafat dalam Berbagai Problematika Kehidupan, h. 87. 
sekarang ini diwarnai oleh sikap dan perilaku atau peradaban yang sekularistik. Paham sekularisme sangat mementingkan hidup kekinian dan menyeret manusia kepada sikap acuh tak acuh akan nilai-nilai moral dan agama serta mengikat diri dengan dunia yang semata-mata bersifat fisik bendawi. ${ }^{15}$

Pandangan di atas secara kontemplatif menunjukkan bahwa kemajuan ilmu pengetahuan dan teknologi merupakan penjelmaan dari pengetahuan ilmiah yang diklaim bebas nilai, kemudian keterasingan perilaku manusia dari nilai-nilai moral dan agama adalah konsekuensi dari karakteristik pengetahuan ilmiah yang skularistik, yang memisahkan urusan dunia dengan urusan moral dan agama (semua urusan duniawi dianggap tidak ada kaitannya dengan agama). Dalam tampilan realitas seperti itulah filsafat harus tampil (sebagai pendekatan) untuk mengkaji moral dan agama bagi kehidupan masyarakat kontemporer dewasa ini. Dengan perkataan lain urgensi filsafat terletak pada penyelesaian persoalan kemanusiaan yang dewasa ini semakin rumit dan kompleks, antara lain mengenai moral dan agama.

Dengan demikian dapat dipahami, bahwa urgensi filsafat adalah dalam rangka memformulasi dan mengaktualisasikan kembali nilai-nilai moral dan agama yang sudah terlalu lama berserakan dan ditinggalkan, sehingga dengan kajian filsafat diharapkan nilai-nilai tersebut dapat tumbuh subur dalam kehidupan praktis manusia, yang akhirnya kehidupan masyarakat komtemporer akan menjadi kuat dalam segala kreativitas dan aktivitas, karena selain berilmu pengetahuan yang luas, juga tidak terpisah atau bercerai dari moral dan agama. Oleh karena itu diharapkan dapat tampil para intelektual yang berkarakter kemanusiaan sejati dan tangguh dalam menghadapi berbagai tantangan yang terjadi dewasa ini, serta senantiasa mengutamakan ketinggian moralitas yang berdasarkan pada agama (Islam) secara komprehensif dan mendasar.

Pandangan tersebut di atas, diperkuat oleh Abuddin Nata dan Amin Abdullah yang mengemukakan sebagai upaya untuk mengembalikan pengetahuan ilmiah yang bebas nilai dan telah membuat keterasingan pradaban manusia dari nilai-nilai moral dan agama, hendaklah dikaji dengan pendekatan filosofis, sehingga apa yang menjadi hakikat, fungsi dan tujuan moral dan agama

15Zubaidi Mastal, IAIN dalam Kritik dan PerspektifPembangunan h. 61. 
dapat dipahami dan diaktualisasikan. ${ }^{16}$ Dalam pada itu dapatlah dikatakan bahwa yang dapat memainkan peran secara optimal dalam pengkajian dan penggalian nilai-nilai hakiki moral dan agama adalah filsafat sebagai metode atau pendekatan, dan secara spesifik dalam tulisan ini akan menjawab persoalan bagaimana fungsi moralitas dan agama dalam kehidupan masyarakat kontemporer dewasa ini.

\section{B. Moral dan Agama}

Moral yang menjadi fokus dalam kajian ini adalah moral menurut agama Islam dalam perspektif filsafat. Hal ini karena secara esensial filosofis moral Islam yang paling sesuai dengan hakikat kemanusiaan, sekaligus dapat berfungsi untuk menyelamatkan manusia atau masyarakat dari kegamangan dan kegelisahan yang tengah dialami dewasa ini. Sebagaimana dikemukakan, bahwa Islam sebagai agama yang dapat menyelamatkan umat manusia dari segala bentuk kegamangan dan kegelisahan spiritual, sangat menekankan persoalan moralitas (sesungguhnya aku diutus untuk menyempurnakan budi pekerti atau moral). Sudah menjadi suatu kesepahaman sebagian besar ulama bahwa akhlak atau moralitas menjadi dasar fundamental dalam berinteraksi dan berkorelasi dengan sesama manusia, dengan alam lingkungan dan bahkan dengan Tuhan. ${ }^{17}$ Oleh karena itu secara filosofis dapat dikatakan, jika tidak ada bangunan akhlak atau moralitas, maka umat manusia akan kehilangan identitasnya sebagai manusia, dan tidak mungkin manusia bisa hidup dalam suatu keharmonisan dan kebersamaan, kebahagiaan dan ketentraman, sehingga identitas manusia sebagai makhluk individual dan sosial tidak dapat terimplementasi secara konkret sesuai fungsinya.

Secara istilah moralitas adalah seperangkat peraturan dan standar yang mengatur baik buruknya tingkah laku manusia. M. Natsir yang dikutip Nainggolan misalnya, mengemukakan bahwa moralitas adalah suatu ukuran untuk menunjukkan mana yang benar dan mana yang salah, dan hal terpenting tentang moralitas adalah bukan hanya ucapan, tetapi bagaimana nilai-nilainya

\footnotetext{
${ }^{16}$ Lihat Abuddin Nata, Metologi Studi Islam (Jakarta, Grafindo Persada, 1999), h. 42 dan Amin Abdullah, Studi Agama Normativitas atau Historisitas (Yogyakarta, Pustaka Pelajar, 1999), h. 101-103.

${ }^{17}$ Himyari Yusuf, Islam dan Kearifan Lokal, Menggali Nilai-nilai Filsafat Hidup Piil Pesenggiri dan Relevansinya dengan Moralitas Islam (Bandar Lampung: Fakultas Ushuluddin IAIN Raden Intan, 2013), h. 55 .
} 
dapat berjalan dalam kenyataan hidup manusia dalam bermasyarakat.18 Dikatakan pula bahwa moralitas Islam adalah bersumber pada al-Qur'an dan Hadis Nabi, dimana keduanya secara esensial meliputi semua aspek kehidupan manusia, seperti ekonomi, sosial, budaya, politik dan sebagainya, termasuk masalah moralitas, dan tidak hanya menyangkut yang bersifat vertikal antara manusia dengan Tuhan, tetapi juga yang bersifat horizontal antara manusia dengan manusia, manusia dengan alam lingkungan.

Mengkaji tentang sumber moralitas Islam, secara empiris terdapat pandangan yang beragam. Misalnya kaum Mu'tazilah berpandangan bahwa akal manusia mampu untuk membedakan yang baik dan yang buruk, seandainya tanpa wahyu atau ketika wahyu tidak-belum diturunkan, sejatinya manusia dengan akalnya mampu untuk menentukan kebaikan dan keburukan. Berbeda halnya dengan pengikut Asy'ariyyah, yang berpandangan bahwa kebaikan dan keburukan adalah otoritas Ilahi melalui wahyu (al-Qur'an). Kebaikan atau keburukan sangat tergantung pada perintah Allah atau dilarang oleh-Nya. Semua yang diperintahkan adalah kebaikan, dan sebaliknya semua yang dilarang adalah keburukan. ${ }^{19}$ Kedua pandangan tersebut sampai sekarang belum menemukan kesepahaman, namun dalam kajian ini tidak akan mempersoalkan perbedaan pandang dari keduanya, yang pasti bahwa moralitas yang dimaksud seperti telah dikemukakan sebelumnya adalah moralitas Islam, karena moralitas Islam yang paling relevan dengan hakikat kemanusiaan.

Mulyadhi Kartanegara mengutip Ibnu Khaldun mengemukakan akal manusia dengan segala kelebihannya, juga memiliki keterbatasan yang mendasar, karena itu manusia membutuhkan sumber lain, selain indera dan akal, yaitu hati (qalb) dan wahyu. ${ }^{20}$ Dalam hal ini Mulyadhi menambahkan, berarti akal tidak dapat dibenturkan dengan wahyu. Dalam Islam, akal adalah karunia Tuhan yang sangat penting, tetapi karena keterbatasannya, maka akal sangat membutuhkan wahyu (al-Qur'an). ${ }^{21}$ Inilah moralitas Islam yang penulis maksud sesuai dengan hakikat kemanusiaan, karena secara filosofis manusia memiliki potensialitas yaitu indera, akal, hati (intuisi) dan yang harus dibimbing oleh

${ }^{18}$ Nainggolan, Pandangan Cendikiawan Muslim tentang Moral Pancasila, Barat dan Islam (Jakarta: Kalam Mulia, 1997), h. 21.

${ }^{19}$ Mulyadhi Kartanegara (etal), Pengatar Studi Islam (Jakarta; Ushul Press, 2011), h. 387.

${ }^{20} \mathrm{Ibid}$., h. 387-388.

${ }^{21}$ Ibid., h. 388-389. 
wahyu Tuhan. Dengan kata lain hakikat manusia adalah makhluk ruhaniah, spiritual ke-Tuhanan, sekaligus sebagai makhluk material jasadiah. Oleh karena itu dapat diinterpretasikan bahwa dimensi ke-Tuhanan dan wahyu-Nya merupakan bagian yang tidak terpisahkan dari kehidupan dan hakikat kesejatian manusia.

Pada umumnya semua manusia menginginkan kebaikan dan kemuliaan (moralitas yang baik). Kebaikan dan kemuliaan (moralitas yang baik) sangat ditekankan dalam Islam karena secara kausalitas perilaku yang baik akan melahirkan ketentraman dan kebahagiaan umat manusia, baik bagi individu maupun masyarakat secara keseluruhan. Kebaikan moralitas yang ditampilkan oleh seseorang individu niscaya akan bermanfaat bagi masyarakat atau seluruh umat manusia, ${ }^{22}$ baik dalam suatu komunitas yang kecil, maupun dalam suatu bangsa dan negara yang lebih luas cakupannya (manusia ibarat satu tubuh). Artinya secara esensial manusia yang satu dengan manusia yang lainnya adalah satu kesatuan yang tidak boleh dipisahkan. Aku ada karena kamu ada dan sebaliknya kamu ada karena aku ada. ${ }^{23}$

Berbagai pandangan tersebut di atas secara filosofis menunjukkan bahwa persoalan moralitas merupakan persoalan manusia dan kemanusiaan. Artinya dalam tataran filosofis hakikat moralitas adalah satu kesatuan yang utuh dengan hakikat manusia. Karena moralitas dalam kajian ini adalah moralitas yang merujuk kepada Islam, maka hakikat manusia yang dimaksud juga sesuai dengan hakikat manusia dalam Islam. Dapat ditegaskan bahwa persoalan moralitas (Islam), adalah persoalan kemanusiaan yang semuanya tidak dapat dipisahkan satu dengan lainnya. Moralitas dalam Islam bersumber pada alQur'an dan Hadis Nabi, selain inderawi, akal dan intuisi. Kemudian bernilai guna untuk harmonisasi kehidupan sesama manusia, alam lingkungan dan bahkan harmonisasi (sebagai wujud ketaatan) dengan Tuhan pencipta alam semesta.

\footnotetext{
22Himyari Yusuf, Islam dan Kearifan Lokal,..., h. 65-66.

${ }^{23}$ Lihat Anton Bakker, Kosmologi Ekologi Filsafat Tentang Kosmos Sebagai Rumah Tangga Manusia (Kanisius, Yogyakarta), 1995. Dalam buku ini dijelaskan secara luas dan mendasar mengenai eksistensi manusia di tengah-tengah kesemestaan. Manusia tidak bisa eksis jika tanpa manusia dan makhluk lain selain dirinya. Teori Bakker ini sejalan dengan pandangan Islam, bahwa manusia itu bersaudara, ibarat satu tubuh, ibarat sebuah bangunan yang saling menguatkan satu dengan lainnya. Dalam Islam juga diajarkan bahwa manusia harus menghormati seluruh makhluk Tuhan yang lain, seperti terhadap alam lingkungan dan lain sebagainya. Hal ini menunjukkan bahwa eksistensi manusia sebagai sentral (makhluk yang paling mulia dan dimuliakan) harus menghormati dan bermoralitas terhadap seluruh makhlukyang ada dalam kesemestaan.
} 
Relevan dengan penjelasan di atas, Nainggolan yang dikutip Himyari Yusuf mengemukakan tujuan moral atau akhlak dibagi dalam dua bagian yaitu tujuan vertikal dan tujuan horizontal. Tujuan vertikal adalah untuk mencapai hubungan yang mendalam antara manusia dengan Tuhannya, dengan cara melaksanakan seluruh ibadah yang diperintahkan. Tujuan horizontal adalah sasaran yang akan dicapai dalam interaksi sesama manusia dan dengan lingkungan, masyarakat, bangsa dan negara. ${ }^{24}$ Pandangan ini dapat diinterpretasikan bahwa secara struktural transendental, moralitas dalam Islam tidak hanya untuk kebaikan perilaku yang bersifat fisik material saja, tetapi juga untuk yang bersifat metafisik spiritual, dan tidak hanya untuk sesama manusia saja, tetapi juga untuk seluruh makhluk lainnya. ${ }^{25}$ Oleh karena itu dapat ditegaskan kembali bahwa secara aksiologis moralitas Islam bernilai guna bagi kebahagian manusia lahiriah dan batiniah, serta bersifat holistik, menyeluruh dan mendasar (moralitas dan Islam adalah dua sisi yang tidak terpisah).

Kemudian mengenai agama dapat dirunut melalui fakta sejarah. Dalam hal ini fakta sejarah menunjukkan bahwa manusia dan persoalan keagamaan tidak pernah ada titik henti. Hal ini menunjukkan bahwa persoalan agama tidak dapat dipisahkan dari kehidupan manusia. Agama sudah menjadi bagian integral dengan kehidupan dan kebudayaan manusia semenjak manusia ada di bumi kesemestaan ini. Agama secara esensial filosofis merupakan dasar fundamental dari keyakinan manusia atas adanya yang Maha Mutlak dan segala yang mengada bersumber dari-Nya. Istilah keyakinan dalam perspektif filsafat Islam identik dengan keimanan, dan keimanan harus terimplementasi dalam kehidupan praktis manusia, baik dalam hubungannya dengan sesama manusia, maupun dengan alam lingkungan (keseimbangan antara keshalehan vertikal dengan keshalehan sosial).

Penjelasan di atas dapat dipahami bahwa keyakinan sebagai cerminan dasar fundamental keimanan merupakan kesatuan yang tidak terpisahkan dengan nilai-nilai yang terkandung dalam agama. Hal tersebut sebagaimana dikemukakan oleh Asy'arie, ${ }^{26}$ bahwa agama pada dasarnya adalah iman, tidak ada agama

${ }^{24}$ Himyari Yusuf, Islam dan Kearifan Lokal,..., h. 68.

25Lihat kembali Himyari Yusuf, Islam dan Kearifan Lokal..., h. 65-70 dibahas secara lebih mendasar dan lebih luas, mengenai manfaat dan tujuan moralitas dalam Islam, baik yang berkaitan dengan tujuan fisik material, maupun tujuan rohaniah spiritual.

26Musa Asy'arie, Filsafat Islam tentang Kebudayaan (Yogyakarta, LESFI, 1999), h. 157. 
tanpa iman, dan iman dalam pengertian agama bukan sekedar pengetahuan dan pengakuan adanya Tuhan, tetapi iman dibangun secara intens dari pengalaman berhubungan secara langsung dengan Tuhan. Lebih lanjut Asy'arie menambahkan bahwa pengalaman iman dicapai melalui proses komunikasi dan dialog pribadi manusia dengan Tuhan dalam berbagai lapangan kegiatan hidup manusia (seluruh aktivitas kehidupan tidak terlepas dari nilai-nilai ke-Tuhanan), maka dalam perspektif filsafat, iman seseorang dapat mengkristal atau menjadi kuat jika ada komunikasi dan dialog kreatif, terbuka dan berkelanjutan yang dilakukan manusia dengan Tuhannya. ${ }^{27}$

Pandangan Asy'arie tersebut secara implisit menunjukkan bahwa iman yang handal hanya dibangun atas dasar komunikasi dan dialog secara berkesinambungan dan langsung dengan yang Maha Mutlak atau Tuhan, bahkan dapat dikatakan iman yang telah mengkristal dan handal adalah tercermin pada seseorang yang merasa dan meyakini bahwa Tuhan senantiasa bersamanya atau paling tidak merasa dilihat oleh Tuhan (ihsan) dalam setiap langkah dan aktivitas. Inilah yang dimaksud iman harus terimplentasi dalam berbagai kreativitas dan aktivitas kehidupan manusia. Seperti kreativitas dan aktivitas dalam bidang ilmu pengetahuan, ekonomi, politik, negarawan, penegak hukum, pegawai negeri, pejabat, pengusaha, pedagang, petani dan lain sebagainya (implementasi iman dalam semua profesi manusia). Oleh karena itu secara falsafati dimensi keimanan dan berbagai nilai yang terkait dengan agama merupakan suatu keniscayaan untuk dijadikan landasan dasar dan diimplementasikan dalam kehidupan praktis masyarakat kontemporer guna mengentaskan berbagai problem kemanusiaan yang tengah terjadi sekarang dan yang akan datang. Dalam hal ini dapat pula dikatakan bahwa nilai-nilai keimanan dalam agama merupakan sentral penyangga dan kekuatan yang luar biasa bagi pencerahan dan kebaikan hidup manusia dalam segala bidang, termasuk persoalan moralitas.

Problem yang sangat mendasar pada kehidupan kontemporer bahwa pemahaman dan pandangan tentang agama secara faktual dapat digolongkan dalam tiga kategori pemahaman. Pertama paham yang menempatkan agama seakan tanpa nilai, tanpa fungsi dan tanpa manfaat bagi kehidupan praktis manusia, sehingga bagi penganut paham ini memandang agama sebagai barang

${ }^{27}$ Ibid, h. 159. 
yang tidak bernilai guna dan tidak perlu dipersoalkan (seperti agnotisisme). Katagori pandangan seperti ini secara teologis tergolong dalam Atheisme Teoritis yang menganggap Tuhan tidak ada atau telah terbunuh dari ranah kehidupan manusia, dan manusia harus mengabaikan nilai-nilai ke-Tuhanan dan seluruh rangkaian ajaran-Nya. Kedua, adalah paham yang menempatkan agama sebagai yang hanya terkait dengan urusan hari akhir atau akherat (dunia lain). Penganut paham ini memandang agama dan nilai-nilai fundamentalnya tidak ada kaitan dengan kehidupan praktis manusia, sehingga kreativitas dan aktivitas praktis manusia dianggap bebas dari nilai-nilai agama. Konkretnya aktivitas dalam bidang politik, hukum, sosial budaya, ketatanegaraan dan lain sebagainya dianggap tidak ada kaitannya dengan nilai-nilai agama. Paham seperti ini juga secara teologis identik dengan atheisme praktis atau bahasa lain disebut sekularisme. ${ }^{28}$ Ketiga adalah paham yang menempatkan agama dan nilai-nilai yang terkandung di dalamnya sebagai yang tidak terpisahkan dari seluruh kreativitas dan aktivitas kehidupan manusia, bahkan agama dengan nilai-nilai fundamentalnya dipandang sebagai identitas kemanusiaan (bagian dari hakikat manusia). Paham yang terakhir ini secara teologis identik dengan Theisme agama samawi, dan inilah yang dianut dan dipegang teguh oleh orang-orang yang masih konsisten dengan agama (Islam), tetap dengan kometment terhadap nilai-nilai ke-Tuhanan dan kemanusiaan, dan tentunya karena mereka memahami hakikat, fungsi dan tujuan agama yang sejatinya. Kedua paham sebelumnya secara realita dapat dikatakan telah membudaya dikalangan sebagian besar masyarakat kontemporer. Oleh karena itu paham-paham tersebut jelas menjadi tantangan hebat dalam era kontemporer dan globalisasi sekarang ini, khususnya bagi para intelektual Muslim yang masih konsisten terhadap agama dan jatidiri kemanusiaan. ${ }^{29}$

${ }^{28}$ Lihat Theo Huijbers, dalam Mencari Allah Pengatar ke dalam Filsafat Ke-Tuhanan (Yogyakarta: Knisius, 1993). Di dalam karya Theo Huijbers ini dijelaskan secara mendalam mengenai berbagai paham ketuhanan yang ada pada masyarakat kontemporer dewasa ini. Antara lain adalah paham agnotisisme yang menganggap kemampuan sangat terbatas untuk mengetahui Tuhan, maka Tuhan tidak perlu dikaji dan dipikirkan. Demikian pula atheisme teoritis dan paraktis keduanya mengetepikan persoalan ke-tuhanan. Tuhan dan agama hanya sekedar candu masyarakat dan sebagainya.

${ }^{29}$ Lihat Adian Husaini, Wajah Peradaban Barat, dari Hegemoni Kristen ke Dominasi SekulaerLiberal (Jakarta: Gema Insani Press), 2014. Dalam buku ini dijelaskan secara luas dan mendasar mengenai historisitas paham keagamaan khusunya di dunia Barat. Pemberontakan terhadap agama Kristen pada abad pertengahan karena memang pada saat itu agama cenderung dijadikan alat kekuasaan, dimonopoli oleh otoritas gereja. Akibatnya peradaban Barat menjadi gelap, atau mengalami masa kegelapan. Dalam kondisi semacam itu, lahirlah paham sekuler yang diperkuat oleh paham 


\section{Korelasi Manusia, Moralitas dan Agama}

Memahami korelasi dan fungsi, moral dan agama pada hakikatnya merupakan hal yang sangat fundamental, karena secara esensial moral dan agama merupakan bagian yang tidak terpisahkan dari kehidupan manusia. Dengan kata lain moralitas dan agama merupakan bagian dari struktur dan hakikat manusia. Sebagaimana telah dikemukakan sebelumnya bahwa kedudukan dan fungsi moral dan agama bagi kehidupan manusia adalah sangat sentral. Karena jika tanpa agama maka tidak akan ada moralitas yang baik, dan sebaliknya tidak ada agama yang tanpa mengandung ajaran tentang moralitas, (khususnya agama Islam). Dalam agama Islam persoalan moralitas yang baik adalah yang sangat diutamakan. Misalnya Nabi Muhammad saw. mengatakan "sesungguhnya tidaklah aku diutus melainkan untuk menyempurnakan akhlak yang mulia".

Herman Khaeron menegaskan bahwa ukuran datangnya kebaikan, pertama ialah dari modal primordial yang diberikan Allah kepada manusia yaitu hati nurani yang bersifat cahaya untuk menerangi sikap manusia. Sebagaimana Nabi bersabda, "Wahai Wabisah, mintalah fatwa pada dirimu, mintalah fatwa pada hatimu (Nabi mengulanginya $3 \mathrm{x}$ ). Kebaikan adalah sesuatu yang membuat jiwa tenang. Dosa adalah sesuatu yang melahirkan kebimbangan dalam dada."30 Hadis ini mempertegas bahwa persoalan moralitas terkait dengan hati nurani manusia, dan hati nurani (qalb) merupakan salah satu potensi dasar yang diberikan Allah kepada manusia yang dalam filsafat dikenal dengan sebutan intuisi. Itu artinya menunjukkan bahwa kebaikan moralitas adalah satu kesatuan dengan kebaikan yang ada dalam diri manusia sendiri yaitu kebaikan hati nurani.

Pada tingkat aplikasi, teori-teori moral atau akhlāq al-karīmah tercermin dalam iman, ibadah, amal shaleh yang terintegrasi secara utuh. Iman selalu memiliki dimensi suprarasional atau spiritual yang mengekspresikan diri dalam tindakan melalui sistem ibadah. Tindakan kebaktian atau ibadah tersebut tidak hanya mengesankan memperkuat rasa iman, dan memberi kesadaran lebih

\footnotetext{
Liberal. Kemudian akhirnya agama mengalami kelemahan, dan dianggap tidakada pengaruhnya dalam kehidupan praktis manusia.

${ }^{30}$ Herman Khaeron, Etika Politik: Paradigma Politik Bersih, Cerdas, Santun, Berbasis Nilai Islam (Bandung: Nuansa Cendikia, 2013), h. 308.
} 
tinggi tentang implikasi iman dalam tindakan, tetapi juga menyediakan pengalaman kerohanian yang tidak kecil artinya, seperti rasa kedekatan dengan Allah yang merupakan wujud makna kehidupan manusia. ${ }^{31}$ Pandangan ini menunjukkan betapa eratnya moralitas atau akhlāq al-karīmah dengan agama (Islam). Ibadah yang dilakukan atas tuntunan agama tidak hanya berbekas pada peningkatan dan penguatan iman saja, tetapi berimplikasi juga terhadap pengalaman kerohanian yang merasa semakin dekat dengan Allah. Dengan demikian dapat dikatakan bahwa secara kausalitas seseorang yang senantiasa merasakan dekat dengan Allah (mantap imannya), niscaya dalam seluruh perilakunya akan sejalan dengan perintah Allah dan sekaligus sesuai dengan makna kehidupan manusia yang sesungguhnya. Ini berarti moralitas dan agama adalah satu spesies yang tidak dapat dipisahkan, dan secara fungsional sangat menentukan kebaikan-kebaikan dalam segala tindakan atau perilaku perbuatan. Singkatnya bagi orang yang kuat imannya, maka akan baik perilakunya, dan akhirnya akan baik pula moralnya (ada keseimbangan antara kesalehan vertikal ke-Tuhanan dengan kesalehan horizontal sosial kemanusiaan.

Herman Khaeron menambahkan bahwa ibadah yang diperintahkan dalam agama dibagi dua, yaitu ibadah dalam arti khusus dan ibadah dalam arti umum. Ibadah dalam arti khusus yang meliputi shalat, puasa, zakat, dan haji, sedangkan ibadah yang disebut umum adalah amal shaleh. Amal shaleh juga merupakan refleksi iman, atau iman yang diwujudkan dengan amal shaleh. Amal shaleh adalah kegiatan berbudaya yang serasi dalam hubungannya dengan lingkungan hidup secara menyeluruh, juga dalam hubungan antara kehidupan duniawi dan ukhrawi, material dan spiritual. ${ }^{32}$ Sebelumnya telah deikemukakan bahwa dasar fundamental agama adalah iman, maka amal shaleh yang merupakan refleksi iman atau iman yang diwujudkan dalam perbuatan amal shaleh adalah implementasi dari pesan-pesan agama (Islam), jika demikian filosofinya, maka amal shaleh (moralitas) merupakan implementasi dari agama, maka itulah sebabnya moralitas dan agama dikatakan sebagai satu kesatuan yang padu, sehingga dapat diinterpretasikan berbicara mengenai moralitas berarti berbicara agama, dan sebalinya bicara agama berarti berbicara moralitas, walaupun senyatanya agama tidak hanya menyangkut persoalan moralitas.

31 Ibid., h. 303-304.

32Ibid., h. 304. 
Pada hakikatnya korelasi manusia, moralitas, dan agama secara interpretasi terletak pada iman, dan tampilan ibadah, amal shaleh dan moralitas atau akhlak yang baik. Oleh karena itu secara filosofis dapat dikatakan, manusia dengan berbagai dimensi dan potensinya adalah selain makhluk bermoral dan sosial kemanusiaan juga adalah makhluk yang berke-Tuhanan. Bahkan secara lebih ekstrem dan mendasar dikatakan bahwa manusia juga dikenal sebagai bayang-bayang Tuhan, karena manusia adalah makhluk yang paling sanggup menyerupai Tuhan dengan dimilikinya ruh, punya lokus atau 'arsh Tuhan. Dalam al-Qur'an Surat al-Hijr ayat 29 disebutkan bahwa setelah fisik manusia diciptakan, kemudian Aku tiupkan ruh-Ku dalam diri manusia ${ }^{33}$

Muhammad Iqbal yang dikutip Hasyimsyah Nasution mengemukakan, manusia mempunyai kemungkinan yang tidak terbatas, mempunyai kemampuan untuk mengubah dunia dan dirinya sendiri, serta mempunyai kemampuan untuk memperindah dunia. Hal ini dimungkinkan karena manusia merupakan wujud penampakan diri dari Aku Yang Akbar. ${ }^{34}$ Haidar Baqir dalam pengantarnya mengatakan keimanan kepada Allah serta pengetahuan tentang baik dan buruk, terdapat dalam wadah yang namanya ruh. Ruh sudah ada ketika perjanjian primordian antara manusia dan Allah, yang di dalam al-Qur'an disebutkan alastu birabbikum dan qālū balā shahidnā. ${ }^{35}$

Pandangan kedua pakar tersebut secara filosofis dapat diinterpretasikan bahwa manusia mempunyai kemampuan untuk berbuat kebaikan di bumi tidak terlepas dari keterhubungannya dengan Allah Pencipta sekalian alam. Bahkan keterhubungan itu tidak bisa dipahami hanya sekedar hubungan tanpa makna, atau hubungan dalam bahasa lisan saja, melainkan hubungan yang radikal, dan menyeluruh, holistik sebagaimana hakikat iman yang telah dikemukakan sebelumnya. Dengan demikian semakin jelas bahwa apapun kreativitas dan aktivitas yang dilakukan manusia sejatinya tidak terlepas dari Tuhan, dan oleh karena itu tidak terlepas dari agama. Sejalan dengan itu dapat dikatakan pula bahwa secara reflektif, dimensi moralitas merupakan implementasi dari nilainilai spiritual (iman) manusia yang korelatif dengan dimensi roh immaterial. Sedangkan dimensi roh immaterial merupakan limpahan atau tuangan dari Tuhan Yang Maha Mutlak, maka tampilan moralitas seseorang secara hakiki

${ }^{33}$ Ahmad Najib Burhani (ed.), Manusia Modern Mendambakan Allah: Renungan Tasawuf Positif (Jakarta: Hikmah, 2002), h. 217.

${ }^{34}$ Hasyimsyah Nasution, Filsafat Islam (Jakarta: Gaya Media Pratama, 1999), h. 200.

${ }^{35}$ Ahmad Najib Burhani (ed.), Manusia Modern Mendambakan Allah .,, h. xvi. 
merupakan manifestasi dan implementasi dari seluruh rangkaian dan struktur fundamental ajaran agama.

Berdasarkan rangkaian struktur fundamental itulah moralitas dan agama terkorelasi dan berfungsi bagi kehidupan manusia. Hal itu ditegaskan Abu Zahrah, ${ }^{36}$ bahwa dalam Islam, kalimat yang terkandung dalam term iman telah dipadatkan dalam dua kalimat syahadat. Sedangkan dua kalimat Syahadat mengandung makna yang sangat mendasar, yaitu hanya Allah sebagai Sang Pencipta, yang menciptakan alam semesta dengan segala isi dan penghuninya, sehingga tidak satu pun yang pantas disembah selain Dia. Artinya dua kalimat Syahadat harus dimaknai bahwa Allah-lah yang menyebabkan segala wujud mengada, maka kewajiban mensyukuri nikmat-Nya adalah sebagai salah satu bentuk mengadanya manusia. Mensyukuri nikmat atau mengimplentasikan nilainilai iman adalah wajib dilakukan manusia dalam segala aspek kehidupannya.

\section{Urgensi Moralitas dan Agama bagi Kehidupan Manusia Kontemporer}

Sebagaimana telah dikemukakan sebelumnya, bahwa ketidak yakinan manusia akan Tuhan dan agama sehingga mengabaikan fungsinya telah mengakibatkan tercampaknya nilai-nilai moralitas, bahkan Tuhan dan agama cenderung dianggap sebagai penghambat kemajuan kehidupan manusia. Agama dianggap tidak ada guna atau manfaat, sehingga moralitas yang dibangun atas dasar agama harus dipinggirkan dari kreativitas dan aktivitas kehidupan manusia (paham sekularistik-atheis praktis).

Berdasarkan pemahaman tersebut di atas, maka perlu perjuangan yang serius untuk mengkaji dan membuktikan bahwa manusia sejatinya adalah makhluk yang berke-Tuhanan, dan berkemanusiaan, (bermoral dan beragama), dan bukanlah makhluk yang berkebinatangan tanpa moral dan agama. Keharusan perjuangan serius itu dimaksudkan guna menyelamatkan bani Adam dan makhluk kesemestaan lainnya dari kebinasaan dan kepunahan moralitas dan agama, serta untuk mengembalikan hidup manusia yang sesuai dengan hakikat, dan tujuan yang ada dalam pesan Sang Pencipta (agama).

36Muhammad Abu Zahrah, Hakikat Aqidah Qurani: Kembali kepada Aqidah yang Benar, terj. Zaid Husain al-Hamid (Jakarta, Bulan Bintang, 1998), h. 7. 
Paradigma kehidupan manusia sekularistik-atheis praktis tersebut di atas sejatinya berawal dari minimnya kemampuan intelektual agama untuk menjawab berbagai problem kehidupan manusia. Zubaidi Mastal mengemukakan bahwa ketidak yakinan manusia kontemporer kepada nilai-nilai keimanan dan agama termasuk moralitas adalah akibat dari ketidak mampuan pakarpakar agama menjawab tantangan menggelobalnya peradaban. Ketidak rasionalan berpikir tentang agama dan sikap konservatif-fanatik buta dari kaum agamawan telah membuat para ilmuan menjadi galau dan muak, (khususnya di dunia Barat abad pertengahan) sehingga mereka menjauhkan diri dari agama. Sebagai konsekuensi dari ketidak rasionalan tersebut terjadilah dikhotomi yang tajam antara ilmu pengetahuan yang menyangkut urusan dunia dengan ilmu agama, dalam pengertian bahwa kemajuan berpikir dan pengembangan ilmu pengetahuan serta peradaban melepaskan diri dari nilai-nilai keagamaan dan kerohanian. ${ }^{37}$

Berdasar pijak dari berbagai pandangan di atas, maka urgensi moralitas dan agama secara falsafati adalah sangat urgen. Oleh karena nilai-nilai moralitas dan agama berkecambah dari dimensi spiritualitas (iman) yang mengada dalam diri setiap manusia, maka nilai-nilai moralitas dan agama secara esensial menjadi tiang penyangga (sangat urgen) bagi segala kreativitas dan aktivitas kehidupan manusia. Pada tataran reflektif dapat dipahami bahwa nilai-nilai moralitas dan agama adalah potensialitas kodrati bagi seluruh umat manusia. Dengan perkataan lain semua aktivitas manusia yang dilandasi oleh nilai-nilai moral dan agama adalah suatu wujud konsistensi akan fitrahnya sebagai makhluk ber-Tuhan. Dalam pada itu Romly mengemukakan, bahwa sepanjang sejarah umat manusia, agama pada hakikatnya mempunyai fungsi dan urgensi dalam meniti kehidupan di dunia ini. Agama sesungguhnya menyangkut seluruh suasana kehidupan manusia. Sejak manusia dilahirkan ia telah membawa suatu tabi'at dalam jiwanya yaitu perasaan keagamaan, maka menjadikan nilai-nilai agama sebagai dasar dalam berbagai aktivitas adalah sesuai fitrah kejadian manusia. ${ }^{38}$ Suparman Syukur juga mengatakan bahwa kedatangan Islam adalah untuk menjadi taḥmatan li - -'-ālamīn. Kerahmatan itu terbawa dan berada

37Zubaidi Mastal, IAIN dalam Kritik dan PerspektifPembangunan, h. 65.

${ }^{38}$ AM. Romly, Fungsi Agama bagi Manusia Suatu Pendekatan Filsafat Oakarta: Bina Reka Pariwara, 1999), h. 78\& 82. 
dengan sendirinya dalam kehidupan umat manusia, karena Islam pada hakikatnya merupakan fitrah kehidupan seluruh alam.39 Suparman Syukur menambahkan bahwa kemudian Islam dinyatakan sebagai agama yang sesuai dengan fitrah manusia, maka agama adalah untuk manusia dan bukan sebaliknya. Artinya agama itu merupakan jalan hidup manusia yang sesuai dengan fitrah kemanusiaannya. ${ }^{40}$ Peter Berger yang dikutip oleh Romly menegaskan bahwa tidak ada jalan lain untuk keluar dari kesemrautan-negatif kehidupan manusia kecuali dengan agama ${ }^{41}$. Relevan dengan itu Muhammad Iqbal mengemukakan bahwa agama tidak dapat dibagi-bagi dalam bagian-bagian tertentu seperti hanya akal semata-mata atau hanya perasaan, ataupun tindakan-tindakan saja. Agama adalah ekspresi dari seluruh potensialitas, fitrah dan kodrati manusia. ${ }^{42}$ Demikian pula Menurut M. Natsir agama merupakan sarana mewujudkan rasa atau nilai-nilai kemanusiaan setinggi-tingginya secara teratur, sehingga agama pada tatanan fungsional memberikan pimpinan kepada hidup manusia agar tetap sebagai manusia yang sesungguhnya dan inilah tujuan tiap-tiap agama. ${ }^{43}$ ]

\section{DAFTAR PUSTAKA}

Abdullah, Amin, Studi Agama, Normativitas atau Historisitas, Yogyakarta: Pustaka Pelajar, 1999.

Abu Zahrah, Muhammad, Hakikat Aqidah Qurani: Kembali Kepada Aqidah yang Benar, terj. Zaid Husain al-Hamid, Jakarta: Bulan Bintang, 1998.

Asy'ari, Musa, Filsafat Islam tentang Kebudayaan, Yogyakarta: LESFI, 1999.

Bakker, Anton, Kosmologi Ekologi Filsafat tentang Kosmos Sebagai Rumah Tangga Manusia, Yogyakarta: Kanisius, 1995.

${ }^{39}$ Suparman Syukur, Epistelogi Islam Skolastik Pengaruhnya pada Pemikiran Modern (Yogyakarta: Pustaka Pelajar, 2007), h. 152.

40 Ibid., h. 153.

${ }^{41}$ AM. Romly, Fungsi Agama bagi Manusia Suatu Pendekatan Filsafat, h. 79.

${ }^{42}$ Ibid., h. 82.

43M. Natsir, Capita Selekta I (Bandung, Sumur, Bandung 1980), h. 115. 
Huijbers, Theo, Mencari Allah, Pengantar Ke-dalam Filsafat Ke-Tuhanan, Yogyakarta: Kanisius, 1993.

Husaini, Adian (et.al.), Filsafat Ilmu Perspektif Barat dan Islam, Jakarta: Gema Insani, 2013.

Wajah Peradaban Barat, dari Hegemoni Kristen ke Dominasi SekulaerLiberal, Jakarta: Gema Insani, 2014.

Khaeron, Herman, Etika Politik, Paradigma Politik Bersih, Cerdas, Santun, Berbasis Nilai Islam, Bandung: Nuansa Cendikia, 2013.

Kartanegara, Mulyadhi (et.al), Pengatar Studi Islam, Jakarta: Ushul Press, 2011.

Liang Gie, The, Suatu Konsepsi Ke-arah Penertiban Bidang Filsafat, Yogyakarta: Karya Kencana, 1987.

Mastal, Zubaidi, IAIN dalam Kritik dan Perspektif Pembangunan, Bandar Lampung: Gunung Pesagi, 1994.

Muhammad, Muslih Filsafat Ilmu, Kajian atas Asumsi Dasar, Paradigma dan Kerangka Teori Ilmu Pengetahuan, Yogyakarta: Belukar, 2004.

Nata, Abuddin, Metodologi Studi Islam, Jakarta: Grafindo Persada, 1999.

Nainggolan, Pandangan Cendekiawan Muslim tentang Moral Pancasila, Barat dan Islam, Jakarta: Kalam Mulia, 1997.

Najib Burhani, Ahmad (ed.), Manusia Modern Mendambakan Allah: Renungan Tasawuf Positif, Jakarta: Hikmah, 2002.

Nasution, Hasyimsyah, Filsafat Islam, Jakarta: Gaya Media Pratama, 1999.

Natsir, Muhammad, Capita Selekta I, Bandung: Sumur Bandung, 1980.

Romly, A.M., Fungsi Agama bagi Manusia, Suatu Pendekatan Filsafat, Jakarta: Bina Reka Pariwara, 1999.

Shihab, M. Quraish, Wawasan al-Qur'an, Bandung: Mizan, 2007.

Syukur, Suparman, Epistemologi Islam Skolastik Pengaruhnya terhadap Pemikiran Islam Modern, Yogyakarta: Pustaka Pelajar, 2007.

Yusuf, Himyari, Filsafat Ilmu, Bandar Lampung; Pusikamla, 1999.

Filsafat dalam Berbagai Problematika Kehidupan, Bandar Lampung; Pusikamla, 1999. 
HimYARI YuSUF: Urgensi Filsafat dalam Kehidupan Masyarakat Kontemporer ....

Islam dan Kearifan Lokal: Menggali Nilai-nilai Filsafat Hidup Piil Pesenggiri dan Relevansinya dengan Moralitas Islam, Lampung; Fakultas Ushuluddin IAIN Raden Intan, 2013. 